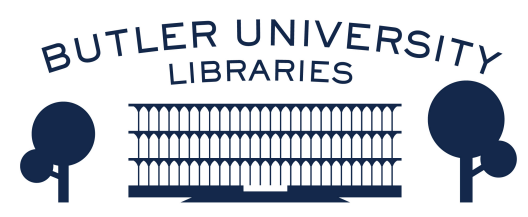

Journal of Hindu-Christian Studies

Volume 13

Article 8

January 2000

\title{
Is Jesus a Hindu? S.C. Vasu and Multiple Madhva \\ Misrepresentations
}

Deepak Sarma

Follow this and additional works at: https://digitalcommons.butler.edu/jhcs

Part of the Religion Commons

\section{Recommended Citation}

Sarma, Deepak (2000) "Is Jesus a Hindu? S.C. Vasu and Multiple Madhva Misrepresentations," Journal of Hindu-Christian Studies: Vol. 13, Article 8.

Available at: https://doi.org/10.7825/2164-6279.1228

The Journal of Hindu-Christian Studies is a publication of the Society for Hindu-Christian Studies. The digital version is made available by Digital Commons @ Butler University. For questions about the Journal or the Society, please contact cbauman@butler.edu. For more information about Digital Commons @ Butler University, please contact digitalscholarship@butler.edu. 


\title{
Is Jesus a Hindu? S. C. Vasu and Multiple Madhva Misrepresentations
}

\author{
Deepak Sarma \\ University of Chicago
}

\section{Introductory Remarks}

Misperceptions and misrepresentations are frequently linked to complicated dynamics between those who are misperceived and those who do the misperceiving. Oftentimes such dynamics are manifestations of underlying social, political, or, in the cases described in this issue of the HinduChristian Studies Bulletin, religious differences. The Hindu and the Christian traditions share a long history of mutual misrepresentations and misperceptions. Many of the authors in this issue of the Bulletin may offer detailed analyses of such misperceptions as they have been described by virtuoso Hindu thinkers such as Ram Mohan Roy, Gandhi-ji, and, in more recent times, BJP activists. In contrast, I will explore a case where mutual misperceptions have established a peculiar dynamic by focusing on the misperceptions that the Madhva school of Vedanta has been influenced by Christian beliefs. There is a theory that the Christian influence in Madhva Vedanta has resulted in a lively and provocative dialogue, one that is not only based on mutual misrepresentations by Christians and Hindus of one another but that actually serves to reinforce such misrepresentations.

I begin by summarizing the Madhva position. Then I turn to a brief account of the Christian misperceptions of their position. Next, I examine Srisa Chandra Vasu's misrepresentation of the misrepresentations. Finally, I draw conclusions from this complex dynamic. ${ }^{1}$

\section{Madhva Vedanta in a Nutshell}

Many readers will be familiar with Madhvacarya's position. However, for those readers who are suffering from ajnana, ignorance (or even mumuksu!), I offer a brief introduction to Madhva theology. This synopsis is not to be considered exhaustive. For the purposes of this limited discussion I appeal to several texts from the Madhva corpus. $^{2}$

Madhva Vedanta supports a dualist position in that it separates all that is real, tattva, into independent, svatantra, and dependent, paratantra, entities. The only completely independent entity is Vishnu, also referred to as brahman. Dependent entities are further subdivided into negation, or non-existents, abhava, and non-negation, existents, bhava. The former concerns epistemological-ontological categories, while the latter is divided into non-sentients, acetana, and sentients, cetana. Sentients alone possess agency. Sentients are also subdivided in a hierarchical fashion. Their hierarchization concerns "proximity" to Vishnu. Proximity, moreover, is consonant with moksa, or release. Madhva ontology, then, is inextricably linked to its eschatology. Sentients, cetana, are either eternally saved, or living in pain. The former set is comprised only of the goddess Sri, Vishnu's consort. The latter set, those living in pain, are either saved, mukta, or not saved, amukta. Mukta are devas, gods, rsis, sages, and the like. Those not saved fall in three categories. This tripartite distinction, jivatraividhya, is Madhva's doctrine of pre- 
destination, svarupatraividhya. The highest group, $u c c a$, those fit for or qualified for release, muktiyogyah, can achieve salvation. Those sentients unable to achieve salvation are either madhya, middling, and nityavartah, bound to the cycle of birth and rebirth, or nica, lowest, tamoyogyah, fit for darkness. This hierarchy, then, strictly correlates ontology with eschatology. That is, the ability, or lack thereof, to attain moksa, proximity to Vishnu, for all sentients is part of the predetermined nature of the Madhva universe.

Madhvacarya proclaims himself to be the third avatara, incarnation, of Vayu, the wind God, the son of Visnu. ${ }^{3}$ Hanuman, the monkey deity of the Ramayana, and Bhima, one of the Pandavas in the Mahabharata, are the first and second. Vayu, namely Madhvacarya, has a dynamic position as a mediator between devotees and Visnu. ${ }^{4} \mathrm{He}$ guides bhaktas, devotees, on their journey towards Vishnu. Muktiyogyah devotees must rely on Vayu/Madhvacarya to serve as intermediary. To what degree they must rely upon him, though, is a matter of debate among Madhva scholars. Not surprisingly, the fact that Madhvacarya claims to be the son of Vishnu is the crux of the mutual misperceptions and misrepresentations between Madhvàs and Christians.

Madhvacarya holds that the universe is governed by pancabheda, five-fold difference. First, there is a difference between brahman, the Highest, and the atman, the self. Second, there is a difference between the atman and jada, material things. Third, there is a difference between each jada. Fourth, there is a difference between jada, material things, and brahman, the Highest. Finally, there is a difference between each atman, self. These five differences are the fundamental bases for arguments regarding ontological, epistemological, and soteriological matters between the Madhva school and all other schools of Vedanta. For example, the Advaita school of Vedanta holds that in moksa, liberation, there is no difference between the atman, the self, and brahman. This position conflicts with all five of the pancabheda tenets of the Madhva school. These disputes inspired the philosophical dialogue between the schools of Vedanta - a dialogue that still continues today in contemporary discussions between scholars of each tradition. The Madhva position summarized here is distorted by some Christian scholars.

\section{Christian Misperceptions}

... considering the fact that Madhva was born and brought up in the neighbourhood of Christians and that the doctrine of bhakti is common to all forms of Vaisnavism and Christianity, there is considerable probability that at least some of these legends grew up under Christian influence. Still more striking, however, is the central article of Madhva belief that Vayu is the son of the Supreme God, Vishnu, and that salvation can be obtained only through him. This is evidently an idea borrowed from Christianity, quite possibly promulgated as a rival to the central doctrine of that faith. ${ }^{5}$

G. A. Grierson makes this strong statement in section three, "Influence of Christianity" of his 1916 article "Madhvas, Madhvacharis" published in Hastings' Encyclopaedia of Religion and Ethics. Grierson summarizes a debate whose origins lay in earlier speculations of A. Burnell and Collins, who wrote about this topic in The Indian Antiquary beginning in $1873 .^{6}$ Clearly it was important for some Christian thinkers to posit influences and to subordinate Madhva Vedanta to Christianity. Madhvacarya's doctrine certainly made itself vulnerable to such claims. The issue is focused centrally around the declaration made by Madhvacarya that he is the avatara of Vayu, the son of Vishnu, and that he is the mediator between devotees and God. It is tangentially related to the possible link between Madhvacarya's unusual doctrine of predestination and similar doctrines found in Christianity, as well as to speculation about the location of Christian settlements in South Asia. Though some may hold that such influences are possible or even probable, the search for such influences is clearly linked to misunderstandings and 
misrepresentations of both Christians of Madhvas and vice versa.

The way in which Grierson's misrepresentative speculation is based on a misperception of Madhva doctrine and issues of orthogenesis is quite obvious. Grierson is simply part of a group of Christian scholars who misrepresent Madhva Vedanta by voicing and publishing such tenuous conclusions. Thankfully, later scholars, both Christian and Hindu, sought to correct the misrepresentation that the relationship between Madhvacarya and Vishnu is identical to the one between Christ and the Christian God. ${ }^{7}$ Glasenapp, the Berlin University Orientalist, for example, argues against the orthogenetic model. In his Madhva's Philosophie des Vishnu-Glauben, he states "Bei näherem Zusehen zeigt sich jedoch, dass die Vergleichspunkte zwischen Vayu und Christus ganz minimale sind."8 Vayu, after all, is neither identical with Vishnu nor is he Vishnu's first son. The comparison is further problematized as Brahma is Vishnu's first son. More importantly, Vayu/Madhva remains governed by pancabheda, five-fold difference and is therefore absolutely and incontrovertibly different from Vishnu. Grierson and others, then, were Christians who misrepresented, misperceived, and misunderstood Madhva Vedanta, one sampradaya, tradition, of Hinduism.

\section{Hindus Misrepresentations of Christianity - the Case of S. C. Vasu}

The examples of Christians misrepresenting Hinduism are plentiful. As evidenced by the "Divali: Festival of Lights, Prayer for Hindus" pamphlet published and distributed in Spring 2000 by the Southern Baptist Convention of the United States, such misrepresentations continue to the present day. ${ }^{9}$ Not surprisingly, the reverse, Hindus misrepresenting Christians, also proliferates. Many of my earliest memories are filled with misrepresentations offered by the Hindu community: e.g. that eating the body and blood of Christ on Sundays was an enactment of cannibalism; that Christian girls intended to convert and corrupt innocent brahmacaris such as myself; and that Santa Claus is a symbol of market economy mechanics and Christian capitalism. Such misrepresentations are not solely the domain of Hindu communities but have a long history among Hindu thinkers. One such thinker was Srisa Chandra Vasu...

S. C. Vasu (1861-1918 CE) was a highly prolific translator who published more than twenty-five creative translations in the late nineteenth and early twentieth centuries. His translations are "creative" because they are very far from literal ones. ${ }^{10}$ Vasu adds materials, both related and unrelated, to his translations. It is difficult to discern between the actual text and the extra materials and analyses. These creative translations provide Vasu with opportunities to offer his own theories at the cost of distorting Madhvacarya's position.

Though he is better known for his work on the Mimamsa school, Vasu also translated several texts of the Madhva school of Vedanta. ${ }^{11}$ His translations of Madhvacarya's commentaries on the Upanisads are found in the Sacred Books of the Hindus series edited by Major B. D. Basu published between 1909 and $1926 .^{12}$ They were published around the same time that Grierson published his article in the Encylcopaedia (1916). This chronology may indicate that Vasu was well aware of the issues of Christian influence that troubled these early Christian Indologists. His knowledge of Grierson's work may also account for his double misrepresentation: a Hindu misrepresentation of a-Christian misrepresentation of Hinduism.

My study of Vasu's translations indicates that he addresses the issue of influence in two places, first in the introductory remarks to his translation of Madhvacarya's Chandogya Upanisad Bhasya and second in his own commentary on concluding sections of the Brhadaranyaka Upanisad Bhasya. ${ }^{13}$ Though his translation of the Chandogya was published in 1910, I begin with the remarks from the Brhadaranyaka, published in 1916. 
4.1 Vasu and the Brhadaranyaka Upanisad In the final section of his Brhadaranyaka Upanisad Bhasya, Madhvacarya states that he is an avatara of Vayu and in the lineage of Bhima and Hanuman. This section is where Vasu makes the controversial (and misleading) identification between Madhvacarya and Christ. Given his creative style, he also adds several portions of texts that are not to be found in Madhvacarya's Bhasya in order to prove his theories. Examinations of several editions of Madhvacarya's Bhasya indicate that the extra texts are not part of the original text. ${ }^{14}$ These extra texts are taken from sections from the $R g$ Veda pertaining to the god Vayu. Madhvacarya, moreover, does not comment on these sections in his commentary on the $R g$ Veda. ${ }^{15}$

Vasu locates his misrepresentations at the end of his creative translation of Madhvacarya's Bhasya. Vasu attempts to explain the relationships between Hanuman, Bhima, and Madhvacarya. He first reminds the reader, though, that Madhvacarya is Christ:

The Commentator [Madhvacarya] now shows, by quoting scriptures, that his coming is prophesized in the Vedas, and therefore this Commentary written by him is authoritative, because he is one of the Aptas or the perfect. $\mathrm{He}$ is, in fact, an incarnation of Vayu or Christ. $[\mathrm{sic}]^{16}$

Surprisingly, Vasu is not saying that Madhvacarya is like Christ. Vayu/ Madhvacarya is Christ!

Vasu then examines the first two avataras of Vayu and their roles in his Christian narrative, asserting that Hanuman, the monkey god of the Ramayana, and Bhima, the most ferocious of the five Pandava brothers of the Mahabharata each incarnations of Christ - save humanity. Hanuman is a messenger of God while Bhima is a warrior against Satan. Vasu states:

Hanumat represents the messenger of God, standing near his throne, ever ready to do his commands. He brings the message of hope to the desponding soul (Sita), when she is frightened by the terrors and temptations of the world, namely, of the lower nature of man. This is the first incarnation of Vayu or Christ in the soul of man. He encourages her and tells her not to lose heart. The soul, thus encouraged and hopeful, becomes stronger and assumes the sterner aspects of Draupadi. ${ }^{17}$

Imagine, Hanuman is Christ himself as well as being an angel!

The first function of Vayu or Christ is that of Hanumat or wisdom. It is the angel that brings the message of hope to the desponding soul, as Hanumat carried the words of Rama to Sita. ${ }^{18}$

Bhima, on the other hand, is a more proactive Christ:

The second manifestation of Vayu takes place now. It is when the soul has reached the stage of Draupadi, who no longer is capable of being snatched away by Ravana or Duryodhana, that the second manifestation of Vayu takes place. The Christ comes now, not as a messenger of God, but as a warrior of the Lord, the destroyer of the Satanic host. $^{19}$

Where could Vasu possibly have found grounds for a Satanic host in the Ramayana and Mahabharata? Are Ravana and Duryodhana Satanic hosts?

Vasu then, comments on five passages taken from the $R g$ Veda to serve his own agenda, proving the identification with Christ. He offers a creative translation of $R g$ Veda 1.141.2.:

His incarnations, as the destroyer of the hosts; is his second form, rich with food, this eternal one sleeps in the home of the seven measurers [sic]

The third form of this powerful Vayu is assumed, in order to give the milk of wisdom to mankind. This is the ten measured form, called the Purnaprajna, which the virgins immaculately conceive. $^{20}$

Then he gives his commentary:

The second Avatara of Vayu is Bhima, the Terrible, the destroyer of the army of the Satanic host. In this form, he governs the Seven Worlds, called the 
seven Measurers. Resting in the seven worlds, $\mathrm{He}$ fights incessantly with all the evils thereof, and keeps them fit for beings to dwell. This form is called rich in food, for it nourishes the seven bodies of man. This is the Christ as world-soul ${ }^{21}$

Vasu turns to Madhvacarya, the third avatara of Vayu:

The third aspect of Vayu or Christ is that which is called Madhva or Purnaprajna or Ananda-tirtha. This is the human aspect or incarnation of Christ, born of women - janayanta yosanah. This incarnation is called dasapramatim or Ten-measured or Fullmeasured, for it is the Perfect manifestation; for ten is the perfect number. This incarnation is called the Vrisabha or the Bull of God, as the Christians call the Christ the Lamb of God. ${ }^{22}$

In this way, Vasu is even able to use similar imagery in the two religions as evidence for his own agenda.

\subsection{Vasu and the Chandogya Upanisad Bhasya}

Vasu's introduction to the Chandogya is even more surprising than his creative translation of the Brhadaranyaka. In these remarks Vasu continues to misrepresent both Christianity and then Hinduism/ Madhva Vedanta. His inclusivist theology has controversial and disturbing implications: he takes the unusual position that Hindus were more Christian than Christians! He peppers his remarks with Christian doctrine and most notably, asserts yet again that Madhvacarya is to be identified with Christ. In the conclusion of his introduction, he states:

Before closing this introduction, I may mention a point on which perhaps Madhva is unique, namely, his claim that he is an incarnation of Vayu, called also Prana, is the highest being next to God. He is called "the beloved son of God", the "servant of God", "the mediator between God and man", "the saviour". The functions assigned by Sri Madhva to Vayu correspond very closely to the Christ principle of the
Christian theology. I have, therefore, not hesitated in translating Vayu and Prana by Christ ${ }^{23}$

Perhaps realizing his identification of Madhvacarya and Christ is so radical as to provoke extreme scepticism, he tries to justify his argument by stating:

Some may think that Madhva's idea is not the same as the Christian idea of Christ. No one can expect exact similarities in such cases, but the approach is still remarkable.

$\mathrm{He}$ further continues to defend the identification:

But more remarkable than this, is the claim of Madhva that he is an incarnation of Vayu. Other authors have been more modest, and left it to their disciples to deify them, but Madhva, like Jesus, boldly lays claim to be the incarnation of Vayu, the son of God. Those who believe in the doctrine of reincarnation, will find no difficulty in accepting this view.

$\mathrm{He}$ furthermore makes an even stronger contention:

Mrs Besant has declared that Jesus was reborn in India as Ramanuja. May it not be that Sri Madhva, the greatest Vaisnava reformer, in the direct line of whose disciples we may count Ramananda, Kabir, Nanak, Tulsi Dass, and the great Chaitanya of Bengal, was himself the incarnation of what he claims himself to be, namely of Vayu or Christ?

Finally, Vasu makes his strongest and most surprising claim:

May it not be that the modern Hindus are really Christians in its better and truer sense, and need not be ashamed to call themselves Vaisnavas, the worshippers of one True God and Christians or adorers of His beloved Son. [sic]

Is Christ really a Hindu? Vasu certainly thinks so!

\subsection{Mutual Misrepresentations}

A curious doubling of misperceptions are at work here. The first is a Hindu misperception of Christianity and the second, a Hindu misperception of a Hindu 
school. The most significant misperception of Christianity on the part of Vasu concerns the fact that he ignores the martyred and sacrificial nature of Christ. Though he ventures a superficial comparison based on the similarity that both are founders of a religious tradition and both claim to have some supernatural relationship to the divine, he ignores the fact that their location in the tradition is radically different. Madhvacarya is not oppressed, never crucified, and never rises from the dead. Furthermore, Vasu either fails to notice or purposely misrepresents the complexity of the relationship between Christ and God, a complexity which has given rise to millennia of arguments and hypotheses.

Many of these misrepresentations would be mitigated if Vasu had engaged in a comparison rather than in an identification. His worst error and the one that makes him most subject to criticism is his statement that Madhvacarya is Christ rather than that he is like Christ. Though such comparison would still involve misrepresentations, they would be less extreme. Either way, he succeeds in misrepresenting Christianity as well as misrepresenting Madhva Vedanta as Christianity. These misrepresentations, moreover, are mutual. The misperceived is also misperceiving!

\section{Notes}

1. I am, as always, indebted to Keri Elizabeth Ames for her editorial suggestions.

2. A large part of this summary is taken from Madhvacarya, Tattvaviveka in Sarvamulagrantha. (B. Govindacarya ed. Bangalore: Akhila Bharata Madhwa Mahamandala, 1969-74). More detailed summaries can be found in B. N. K. Sharma, Philosophy of Sri Madhvacarya. (Delhi: Motilal Banarsidass, 1986) and other introductory texts on Madhva Vedanta. For an excellent summary of Madhva epistemology, see Suzanne Siauve, La Doctrine de Madhva. (Pondichery: Institut Français D'Indologie, 1968).

3. Madhvacarya, Brhadaranyaka Upanisad Bhasya in Sarvamulagranthah.
Govindacarya ed. Bangalore: Akhila Bharata Madhwa Mahamandala, 1969-74), 6.5.5.

4. See Madhvacarya, Chandogya Upanisad Bhasya in Sarvamulagranthah. (B. Govindacarya ed. Bangalore: Akhila Bharata Madhwa Mahamandala, 1969-74), 3.15.2 and 5.2. See Helmuth von Glasenapp, Madhva's Philosophie des Vishnu-Glauben. (Bonn: Kurt Schroeder, 1923), pp. 73-74 for more references.

5. G. A. Grierson, "Madhvas, Madhvacharis" in Encyclopaedia of Religion and Ethics, Vol. 8. (Hastings, ed. NY: Charles Scribner's Sons, 1916), p. 234.

6. Grierson, "Madhvas, Madhvacharis", p. 234, n. 3 , p. 235, n. 1 .

7. Of course the relationship between Christ and the Christian God and the integrity of the Trinity is a matter of some debate among Christians and Christian scholars, a debate that I happily leave them to resolve.

8. Glasenapp, Madhva's Philosophie, p. 34.

9. International Mission Board, "Divali: Festival of Lights, Prayer for Hindus". (Southern Baptist Convention, 1999).

10. I am indebted to Paul Griffiths for the phrase "creative translation".

11. Vasu was not the first to publish Madhva texts in English as S. Subba Rau published translations of the Brahma Sutra Bhasya and Madhvacarya's commentary on the Gita in 1904 and 1906 respectively. S. Subba Rao, The Vedanta-Sutras with the commentary of Sri Madhwacharya. (Tirupati: Sri Vyasa Press, 1904). S. Subba Rao, The Bhagavad Gita; Translation and Commentaries in English according to Sri Madhwacharya's Bhashyas. (Madras: Minerva Press, 1906).

12. B. D. Basu (ed.), Sacred Books of the Hindus. (Allahabad: B.D. Basu, 1909-1926).

13. S. C. Vasu, Chhandogya Upanisad with the Commentary of Iri Madhvacharya, Sacred Books of the Hindus Vol. 3. (Allahabad: B.D. Basu, 1910). S. C. Vasu, Brihadaranyaka Upanisad with the Commentary of Sri Madhvacharya, Sacred Books of the Hindus Vol. 14. (Allahabad: B.D. Basu, 1916).

14. See, B. Govindacarya (ed.), Sarvamulagranthah. (Bangalore: Akhila Bharata Madhwa Mahamandala, 1969-74), and V. Prabhanjanacharya ' (ed.), Sarvamulagranthah. (Bangalore: Sri Vyasa Madhwa Seva Pratisthana, 1999).

15. See Madhvacarya, Rgbhasya in Sarvamula- 
granthah. (B. Govindacarya ed. Bangalore: Akhila Bharata Madhwa Mahamandala, 1969-74).

16. Vasu, Brihadaranyaka Upanisad, p. 708. Brackets mine.

17. Tbid., p. 709.

18. Tbid., p. 711.

19. Tbid., p. 709.

20. Ibid., p. 711. The same passage is translated by R. T. H. Griffiths. Readers may note the extent to which Vasu's translation is creative.

Wonderful, rich in nourishment, he dwells in food; next in the seven auspicious Mothers is his home.
Thirdly, that they might drain the treasures of the Bull, the maidens brought forth him for whom the ten provide.[sic]

R. T. H. Griffiths, Hymns of the Rgveda, Vol. 1. (Varanasi: Chowkhamba Sanskrit Series Office, 1963), p. 195. Vasu provides the translation for the reader in his commentary. See Vasu, Brihadaranyaka Upanisad, p. 710.

21. Ibid.

22. Ibid.

23. Vasu, Chhandogya Upanisad, xiv-xv. All citations in this section are from Vasu, Chhandogya Upanisad, pp. xiv-xv. 